J. Clin. Chem. Clin. Biochem.

Vol. 23, 1985, pp. 277-281

\title{
$\alpha_{1}$-Antitrypsin:
}

\section{The Effect of Anticoagulants on the Trypsin Inhibitory Capacity, Concentration and Phenotype}

\author{
By R.W.Berninger and Maria F. Teixeira
}

Pulmonary Division, Department of Pediatrics, New England Medical Center Hospitals Inc., Tufts University School of Medicine, Boston, MA, USA

(Received March 30/November 5, 1984)

Summary: The effects of anticoagulants on the determination of both trypsin inhibitory capacity and the concentration of $\alpha_{1}$-antitrypsin measured by radial immunodiffusion, and on the $\alpha_{1}$-antitrypsin phenotype were investigated. These results were compared with those obtained for serum. The following anticoagulants were investigated: sodium citrate; sodium oxalate; buffered citrate; potassium oxalate/sodium fluoride; sodium heparin; and potassium EDTA. It was found that plasmas from all of the anticoagulants, except sodium heparin, resulted in apparently significant decreases of both trypsin inhibitory capacity and concentration of $\alpha_{1}$-antitrypsin measured by radial immunodiffusion, relative to serum. These decreases were not simply due to dilution by anticoagulants. Using both acid starch gel electrophoresis followed by immunofixation and isoelectric focusing in agarose, no interference was found in the phenotype determination.

It is concluded that serum should be used to measure the trypsin inhibitory capacity or the concentration of $\alpha_{1}$-antitrypsin by radial immunodiffusion, although plasma is also suitable provided that sodium heparin is used as the anticoagulant. The $\alpha_{1}$-antitrypsin phenotype can be determined with either serum or any of the plasmas. None of the anticoagulants employed in this study was present in excess.

$\alpha_{1}$-Antitrypsin: Die Wirkung von gerinnungshemmenden Substanzen auf die Bestimmung von Hemm-Kapazität, Konzentration und Phänotyp

Zusammenfassung: Die Wirkung von gerinnungshemmenden Substanzen auf die Bestimmung der Trypsinhemmenden Kapazität und die durch radiale Immundiffusion gemessene Konzentration von $\alpha_{1}$-Antitrypsin sowie auf den $\alpha_{1}$-Antitrypsin-Phänotyp wurde untersucht. Die Ergebnisse wurden mit den für Serum erhaltenen verglichen. Folgende Substanzen wurden zur Hemmung der Gerinnung eingesetzt: Natriumcitrat, Natriumoxalat, Citratpuffer, Kaliumoxalat/Natriumfluorid, Natriumheparinat und das Kaliumsalz von EDTA. Plasmen, die mit diesen Substanzen - ausgenommen Natriumheparinat - gewonnen worden waren, ergaben auf Serum bezogen offenbar signifikant niedrigere Trypsin-hemmende Kapazität und niedrigere mit der radialen Immundiffusion bestimmate Konzentrationen von $\alpha_{1}$-Antitrypsin.

Diese Verminderungen waren nicht einfach durch Verdünnung mit den zur Gerinnungshemmung benutzten Subștanzen bedingt. Sowohl mit saurer Stärkegelelektrophorese und nachfolgender Immunfixation als auch mit isoelektrischer Fokussierung in Agarose wurde keine Störung der Bestimmung des Phänotyps beobachtet.

Zur Bestimmung der Trypsin-hemmenden Kapazität oder zur Bestimmung der $\alpha_{1}$-Antitrypsin-Konzentration mit der radialen Immundiffusion sollte also Serum eingesetzt werden, obwohl auch Plasma - voraussgesetzt, es wurde mit Natriumheparinat gewonnen - geeignet ist. Der $\alpha_{1}$-Antitrypsin-Phänotyp kann entweder mit Serum oder mit jedem der verschiedenen Plasmen bestimmt werden. Keine der in dieser Studie angewandten gerinnungshemmenden Substanzen war im Überschuß vorhanden.

Acknowledgement of Support: The authors were supported in part by Grant AM 28272 from the National Institute of Arthritis, Diabetes, and Digestive and Kidney Diseases. 


\section{Introduction}

$\alpha_{1}$-Antitrypsin is one of several well characterized protease inhibitors in blood $(1,2)$. A deficiency of $\alpha_{1}$-antitrypsin can lead to liver disease in children (3) or lung disease between the third and fourth decade of life (4). $\alpha_{1}$-Antitrypsin accounts for over $90 \%$ of the trypsin inhibitory capacity in blood (5). Since the trypsin inhibitory capacity correlates with the amount of $\alpha_{1}$-antitrypsin measured immunologically $(6,7)$, many laboratories prefer to quantitate the amount of $\alpha_{1}$-antitrypsin by the easier and faster trypsin inhibitory capacity method (8). A low trypsin inhibitory capacity would indicate the possibility of a deficient $\alpha_{1}$-antitrypsin phenotype or perhaps the presence of a non-functional variant of $\alpha_{1}$-antitrypsin, although such a non-functional variant has not yet been found.

It has been recommended that serum should be used for $\alpha_{1}$-antitrypsin phenotype and concentration measurements (9). It has been reported that the functional assay of $\alpha_{1}$-antitrypsin gives different values for serum and plasma (9). However, we can find no comprehensive comparison of serum and plasma for the determination of trypsin inhibitory capacity, or the concentration of $\alpha_{1}$-antitrypsin by radial immunodiffusion. Occasionally, plasma from a given patient may be the only fluid available for determination of the $\alpha_{1}$-antitrypsin phenotpye and concentration. Serum may not be available for various reasons, such as intercurrent transfusions, the amount of blood already taken from a patient, or unavailability of a patient. Furthermore, commercial suppliers of radial immunodiffusion plates state that the level of $\alpha_{1}$-antitrypsin can be measured in serum or plasma but make no statement concerning the possible problems (or advantages) of using plasma. Therefore, the influence of anticoagulants on the trypsin inhibitory capacity, radial immunodiffusion and $\alpha_{1}$-antitrypsin phenotype needs to be investigated to ascertain plasma suitability for assays.

The purpose of these studies was to compare plasmas and serum from the same individuals for the determination of trypsin inhibitory capacity and for the measurement of $\alpha_{1}$-antitrypsin by radial immunodiffusion, in order to determine the possible effects of anticoagulants on the these parameters.

We found that plasma containing sodium citrate, sodium oxalate, buffered citrate, potassium oxalate/ sodium fluoride or potassium EDTA have lower trypsin inhibitory capacity and radial immunodiffusion values than serum or plasma containing sodium heparin. There was no interference in the determination of the $\alpha_{1}$-antitrypsin phenotype in plasmas, using both acid starch gel electrophoresis followed by immunofixation and isoelectric focusing in agarose.

\section{Materials and Methods}

The trypsin inhibitory capacity of the serum and plasmas was measured in duplicate $(4,10)$. Briefly; $15 \mu$ l of sample (serum or plasma) were added to $3.8 \mathrm{ml}$ (sample tube) and $4.0 \mathrm{ml}$ (blank tube) of assay buffer $\left(0.1 \mathrm{~mol} / \mathrm{l}\right.$ Tris, $0.02 \mathrm{~mol} / 1 \mathrm{CaCl}_{2}$, $\mathrm{pH}$ 8.2) followed by addition of $200 \mu \mathrm{l}$ of trypsin solution $(0.2$ $\mathrm{g} / \mathrm{l}$ in $0.0025 \mathrm{~mol} / \mathrm{l} \mathrm{HCl}$ ) in a timed fashion to the sample tubes (blank tubes do not receive trypsin solution) and to $3.8 \mathrm{ml}$ of assay buffer alone (the trypsin control) at $25^{\circ} \mathrm{C}$. After exactly $15 \mathrm{~min}, 4.0 \mathrm{ml}$ of benzoyl- $D L$-arginine-p-nitroanilide hydrochloride ( $0.435 \mathrm{~g} / \mathrm{l}, \mathrm{ICN}$ Pharmaceutical) were added. After exactly $10 \mathrm{~min}, 1.0 \mathrm{ml}$ of acetic acid $(300 \mathrm{ml} / \mathrm{l})$ was added. The tubes were read at $410 \mathrm{~nm}$ and the trypsin inhibitory capacity ( $g$ trypsin inhibited per 1 of sample) calculated in the usual fashion $(4,10)$ after subtraction of the blanks from sample and the trypsin control tubes. Results were expressed as "per cent normal" of a standard pool (provided by Dr. Pierce at the University of Washington). The \% trypsin inhibitory capacity change relative to serum was calculated:

$\%$ trypsin inhibitory capacity change $=$

$$
=\frac{\% \text { Normal (plasma) }-\% \text { Normal (serum) }}{\% \text { Normal (serum) }} \times 100 \%
$$

The concentration of $\alpha_{1}$-antitrypsin was quantitated immunochemically by the radial immunodiffusion technique using commercial M-Partigen plates (Calbiochem-Behring) and the supplied standardized serum. An aliquot of the standard serum used in the trypsin inhibitory capacity assay above was included on each radial immunodiffúsion plate as an additional control. The diameters on the radial immunodiffusion plate were measured 3 times. The \% radial immunodiffusion change relative to serum was calculated:

$\%$ radial immunodiffusion change $=$

$$
=\frac{\mathrm{g} / \mathrm{l}(\text { plasma })-\mathrm{g} / \mathrm{l}(\text { serum })}{\mathrm{g} / \mathrm{l} \text { (serum) }} \times 100 \%
$$

The phenotype of $\alpha_{1}$-antitrypsin was determined by both acid starch gel electrophoresis (11) followed by immunofixation (12) and isoelectric focusing in agarose (13). Hydrolysed starch was purchased from Connaught Laboratories (Lot \#365-1); antibody (goat) to human $\alpha_{1}$-antitrypsin was obtained from Kallestad Laboratories; agarose-EF (Batch \#1) and carrièr ampholytes were purchased from LKB.

Blood was drawn into a stèrile, $4 \mathrm{ml}$ Vacutainer (silicone coated: - Becton, Dickinson and Co.), and then into a $3 \mathrm{ml}$ (total volume) sterile Vacutainer or sterile Venoject tubes (KimbleTerumo) containing: $0.3 \mathrm{ml}$ of $38 \mathrm{~g} / 1$ sodium citrate; $0.3 \mathrm{ml}$ of $0.1 \mathrm{~mol} / \mathrm{l}$ sodium oxalate $(4.0 \mathrm{mg}$ sodium oxalate and $0.06 \mathrm{mg}$ sorbic acid); $0.3 \mathrm{ml}$ of $0.105 \mathrm{~mol} / 1$ buffered citrate $(7.41 \mathrm{mg}$ trisodium citrate dihydrate and $1.32 \mathrm{mg}$ citric acid monohydrate); $6 \mathrm{mg}$ potassium oxalate and $7.5 \mathrm{mg}$ sodium fluoride; 286 USP units of solid sodium heparin; and $0.06 \mathrm{ml}$ of $75 \mathrm{~g} / \mathrm{l}$ potassium EDTA. The serum and plasmas were drawn and processed together in the following manner:

serum -0.5 hour at room temperature; 3 hours at $10^{\circ} \mathrm{C}$; centrifugation at $1000 \mathrm{~g}$ for 30 minutes at $4^{\circ} \mathrm{C}$;

plasma - $15 \mathrm{~min}$ in wet ice; centrifugation at $1000 \mathrm{~g}$ for 30 min at $4^{\circ} \mathrm{C}$;

and storage of small aliquots of supernatants at $-70^{\circ} \mathrm{C}$.

The $p$ values were calculated by comparing the trypsin inhibitory capacity and radial immunodiffusion values of the various plasmas and corresponding serum using a correlated ttest (STATPAK, Northwest Analytiçal). 


\section{Results}

The per cent normal trypsin inhibitory capacity for 8 healthy subjects was $106 \pm 9.9$. The per cent trypsin inhibitory capacity changes for the various plasmas are listed in table 1.

The inter assay and intra assay coefficients of variation for the trypsin inhibitory capacity assays were $1.9 \%$ and $3.2 \%$, respectively. All plasmas except sodium heparin had a significant decrease in per cent normal trypsin inhibitory capacity relative to serum (tab. 1).

The concentration of $\alpha$-antitrypsin for the 8 subjects was $2.262 \pm 0.215 \mathrm{~g} / \mathrm{l}$ and for the same standard used in the trypsin inhibitory capacity assay on 7 different plates was $2.381 \pm 0.119 \mathrm{~g} / \mathrm{l}$.

The inter assay and intra assay coefficients of variation for the radial immunodiffusion assays were $3.5 \%$ and $5.0 \%$, respectively. All plasmas except sodium heparin showed a significant decrease in concentration relative to serum (tab. 1).

All 8 subjects were found to have the PI M phenotype of $\alpha_{1}$-antitrypsin by both acid starch gel electrophoresis followed by immunofixation and isoelectric focusing in agarose. The final total volume of all plasma tubes was $3.02 \pm 0.12 \mathrm{ml}$.

\section{Discussion}

While it has been reported that plasma exhibits a lower trypsin inhibitory capacity than serum (9), we have found no systematic study of the effect of anticoagulants on either the trypsin inhibitory capacity or radial immunodiffusion. The study reported here indicates that the use of various plasmas (except those prepared with sodium heparin) instead of the corresponding serum results in significantly lower trypsin inhibitory capacities and significantly lower values for $\alpha_{1}$-antitrypsin measured by radial immunodiffusion. These decreases were not due to dilution. It has been reported that the trypsin inhibitory capacity of serum is markedly reduced when gram-negative bacteria are present (14); however, the samples were processed to prevent bacterial contamination and growth. From our studies, it would appear that plasma treated with sodium heparin is suitable for measurement of trypsin inhibitory capacity or analysis by radial immunodiffusion.

Our results for trypsin inhibitory capacity and $\alpha_{1-}$ antitrypsin concentration for sodium citrate plasma show the same trend, but of greater magnitude than those calculated, i. e. $-5.6 \%$ and $-8.0 \%$, respectively, in another study (15). However, we calculated these differences from median values and not the individual paired serum and plasma values. Furthermore, the trypsin inhibitory capacity (15) was determined by an automated continuous assay with a shorter incubation time, different concentrations and benzoyl- $L$-arginine- $p$-nitroanilide as a substrate at $\mathrm{pH} 7.80$, whereas our trypsin inhibitory capacity is an end point determination $(4,10)$, using benzoyl$D, L$-arginine- $p$-nitroanilide at $\mathrm{pH}$ 8.2. These differences may account for the differences in magnitude of the trypsin inhibitory capacity. Our radial immunodiffusion results for sodium citrate agree with those of another study in which the concentration of $\alpha_{1}$-antitrypsin was $15.4 \%$ lower (negative value) compared to serum diluted in the same proportion as plasma (16). Surprinsingly, the concentration of $\alpha_{2}$-macroglobulin in sodium citrate plasma was $6.7 \%$ lower compared to proportionally diluted serum (16). The authors (16) suggest that the greater concentration of $\alpha_{1}$-antitrypsin and $\alpha_{2}$ macroglobulin in serum may be due to inhibitorprotease complexes formed during coagulation and

Tab. 1. \% Trypsin inhibitory capacity and radial immunodiffusion changes in plasma.

\begin{tabular}{|c|c|c|c|c|c|}
\hline Plasma & $\begin{array}{l}\% \text { Trypsin inhibitory } \\
\left.\text { capacity change }{ }^{1}\right)^{2} \text { ) }\end{array}$ & $\left.\mathrm{p}^{3}\right)$ & $\begin{array}{l}\% \text { Radial immuno- } \\
\left.\text { diffusion change }{ }^{1}\right)^{2} \text { ) }\end{array}$ & $\left.\mathrm{p}^{3}\right)$ & $\begin{array}{l}\text { Calculated } \\
\% \text { change }\end{array}$ \\
\hline $\begin{array}{l}\text { Sodium citrate } \\
\text { Sodium oxalate } \\
\text { Buffered citrate } \\
\text { Potassium oxalate/sodium fluoride } \\
\text { Sodium heparin }\end{array}$ & $\begin{array}{l}-16.4 \pm 2.4(\mathrm{~N}=8) \\
-15.8 \pm 2.4(\mathrm{~N}=8) \\
-13.8 \pm 4.0(\mathrm{~N}=8) \\
-12.0 \pm 3.2(\mathrm{~N}=8) \\
-4.9 \pm 3.8(\mathrm{~N}=5) \\
+5.7 \pm 2.3(\mathrm{~N}=3)\end{array}$ & $\begin{array}{l}<0.01 \\
<0.01 \\
<0.01 \\
<0.01 \\
\text { NS } \\
\text { NS }\end{array}$ & $\begin{array}{l}-27.1 \pm 5.7(\mathrm{~N}=8) \\
-24.1 \pm 5.2(\mathrm{~N}=8) \\
-15.4 \pm 12.4(\mathrm{~N}=8) \\
-18.0 \pm 9.4(\mathrm{~N}=8) \\
-3.9 \pm 4.1(\mathrm{~N}=8) \\
-81+22(\mathrm{~N}=8)\end{array}$ & $\begin{array}{l}<0.01 \\
<0.01 \\
<0.02 \\
<0.01 \\
<0.05\end{array}$ & $\begin{array}{r}-10 \\
-10 \\
-10 \\
0 \\
0\end{array}$ \\
\hline Potassium EDTA & $-3.3 \pm 2.3(\mathrm{~N}=8)$ & $<0.01$ & $-8.1 \pm 2.2(\mathrm{~N}=8)$ & $<0.01$ & -2 \\
\hline
\end{tabular}

1) A negative value represents a decrease in the measured trypsin inhibitory capacity or radial immunodiffusion value, whereas a positive value represents an increase in the measured trypsin inhibitory capacity or radial immunodiffusion value. See Materials and Methods for calculation.

$\left.{ }^{2}\right)$ Values listed are the mean $\pm \mathrm{SD}$ of $\%$ trypsin inhibitory capacity change or \% radial immunodiffusion change for $\mathrm{N}$ samples.

3) Comparison of $\%$ normal trypsin inhibitory capacity and radial immunodiffusion $(\mathrm{g} / \mathrm{l})$ for serum with the various plasmas. 
note that the concentration of antithrombin III was found to increase after complexation with thrombin.

Surprinsingly, the decrease in $\alpha_{1}$-antitrypsin (measured immunologically by the radial immunodiffusion technique) was greater than that shown in the trypsin inhibitory capacity assay, particularly in the plasmas where there was little or no dilution (see above, and see tab. 1). The radial immunodiffusion technique measures the total amount of $\alpha_{1}$-antitrypsin present, regardless of its functional status. We do not believe that these radial immunodiffusion values are in error since the following controls were employed to minimize technical errors:

1) the same set of diluted serum standards was used to generate the calibration curve on each plate;

2) a diluted aliquot of the serum sample used as a standard in the trypsin inhibitory capacity was included on every plate with consistent and reproducible results; and

3 ) the diameter of each sample was measured 3 times. We did not quantitate the amount of $\alpha_{1}$-antitrypsin by the electroimmunodiffusion technique since the ionic content of the various plasmas could give rise to artifacts.

While this work does not identify the mechanism which accounts for the lower trypsin inhibitory capacity and radial immunodiffusion values obtained with plasmas, it does document that these potential problems exist for plasmas produced with sodium citrate, sodium oxalate, buffered citrate, potassium oxalate/sodium fluoride and potassium EDTA. Since the decrease in $\alpha_{1}$-antitrypsin was evident functionally (trypsin inhibitory capacity) and immunochemically (radial immunodiffusion), we would speculate that the cause' is probably associated with the $\alpha_{1-}$ - antitrypsin itself and not due to interference of the anticoagulants with the trypsin inhibitory capacity or radial immunodiffusion assays. More work is needed to elucidate the mechanism(s) of the decreases associated with trypsin inhibitory capacity and radial immunodiffusion assays for plasmas.

In our studies, none of the anticoagulants interfered with the determination of the $\alpha_{1}$-antitrypsin phenotype by acid starch gel electrophoresis followed by immunofixation or by isoelectric focusing in agarose. However, it should be noted that heparin in excess interferes with the determination of the $\alpha_{1}$ antitrypsin phenotype by acid starch gel electrophoresis (17) or isoelectric focusing in polyacrylamide $(18,19)$. Sodium EDTA does not interfere with determination of the $\alpha_{1}$-antitrypsin phenotype by isoelectric focusing in polyacrylamide $(18,19)$. It has also been reported that bacterial contamination $(14,17)$ or age $(18,19,20)$ or extended exposure to room temperature $(17,21)$ interferes with determination of the $\alpha_{1}$-antitrypsin phenotype. These potential problems were avoided in our studies.

In conclusion, this work indicates that the trypsin inhibitory capacity and radial immunodiffusion can be measured in plasma prepared with sodium heparin. The phenotype can be determined with any of the plasmas or sera tested, using either acid starch gel electrophoresis followed by immunofixation or isoelectric focusing in agarose.

\section{Acknowledgements}

The authors thank Dr. Henry Drokin for helpful discussions and both Dr. Stephen Alpert and Dr. Cody Meissner for drawing the blood used in these studies. The excellent typing assistance of Diane Connors and Irene Hartford is gratefully acknowledged. The authors thank Dr. Virginia Berninger for assistance with the statistics.

\section{References}

1. Fagerhol, M. K. \& Cox, D. W. (1981) Advances in human genetics (Harris, H. \& Hirschhorn, K., eds.) Plenum Press, New York, pp. 1-62.

2. Gadek, J. E. \& Crystal, R. G. (1983) The metabolic basis of inherited disease (Stanbury, J. B., Wyngaarden, J. B., Fredrickson, D. S., Goldstein, J. L. \& Brown, M. S., eds.) McGraw-Hill, Inc., New York, pp. 1450-1467.

3. Sharp, H. L., Bridges, R. A., Krivit, W. \& Freier, E. S. (1969) J. Lab. Clin. Med. 73, 934-939.

4. Eriksson, S. (1965) Acta. Med. Scand. 177, Suppl. 432, $1-85$.

5. Jacobsson, K. (1955) Scand. J. Clin. Lab. Invest. 7, Suppl. $14,55-102$

6. Talamo, R. C., Allen, J. D., Kahan, M. G. \& Austen, K. F. (1968) N. Engl. J. Med. 278, 345-351.

7. Talamo, R. C., Langley, C. E. \& Hyslop, N. E., Jr. (1972) Pulmonary emphysema and proteolysis (Mittman, C., ed.) Academic Press, New York, pp. 167-172.

8. Talamo, R. C. (1975) Pediatrics 56, 91-99.

9. Talamo, R. C., Bruce, R. M., Langley, C. E., Berninger, R. W., Pierce, J. A., Brant, L. J. \& Duncan, D. B. (1978) $\alpha_{1}$-Antitrypsin laboratory manual. National Heart, Lung and Blood Institute. U.S. Department of Health, Education, and Welfare, Public Health Service, National Institutes of Health, DHEW Publication No. (NIH) 78-1420. Maryland, pp. 9-11.

10. Talamo, R. C., Bruce, R. M., Langley, C. E., Berninger, R. W., Pierce, J. A., Brant, L. J. \& Duncan, D. B. (1978) $\alpha_{1}$-Antitrypsin laboratory manual. Nationàl Heart, Lung and Blood Institute. U.S. Department of Health, Education, and Welfare, Public Health Service, National Institutes of Health, DHEW Publication No. (NIH) 78-1420. Maryland, pp. 15-35.

11. Talamo, R. C., Bruce, R. M., Langley, C. E., Berninger, R. W.; Pierce, J. A.; Brant, L. J. \& Duncan, D. B. (1978) $\alpha_{1}$-Antitrypsin laboratory manual. National Heart, Lung 
and Blood Institute. U.S. Department of Health, Education, and Welfare, Public Health Service, National Institutes of Health, DHEW Publication No. (NIH) 78-1420. Maryland, pp. 37-64.

12. Arnaud, P., Wilson, G. B., Koistinen, J. \& Fudenberg, H. H. (1977) J. Immunol. Methods 16, 221-231.

13. Qureshi, A. R. \& Punnett, H. H. (1982) Anal. Biochem. $125,335-338$.

14. Lieberman, J., Kaneshiro, W. \& Gaidulis, L. (1975) J. Lab. Clin. Med. 86, 7-16.

15. Witt, V. I. \& Tritschler, W. (1982) J. Clin. Chem. Clin. Biochem. 20, 587-591.

16. Göbel, U., Petrich, C., von Voss, H. \& Schmelzer, L. (1978) Eur. J. Pediatr. 129, 117-124.
17. Cook, P. J. L. (1975) Ann. Hum. Genet. 38, 275-287.

18. Jeppsson, J.-O. \& Franzén, B. (1982) Clin. Chem. 28, 219-225.

19. Klasen, E. C. \& DeBrij, R.-J. (1979) Clin. Chim. Acta 95, $391-394$.

20. Conrad, S. A., McCormick, G. M. \& George, R. B. (1979) Am. J. Clin. Pathol. 71, 549-553.

21. Arnaud, P., Chapuis-Cellier, C., Wilson, G. B., Koistinen, J., Allen, R. C. \& Fudenberg, H. H. (1977) Electrofocusing and isotachophoresis: Proceedings of the International Symposium August 2-4, 1976, Hamburg, Germany (Radola, B. J. \& Graesslin, D. eds.) Walter de Gruyter, Berlin, pp. 265-272.

Ronald W. Berninger, Ph. D.

New England Medical Center Hospitals Inc.

Department of Pediatrics, Box 208

171 Harrison Avenue

Boston, MA 02111

USA 


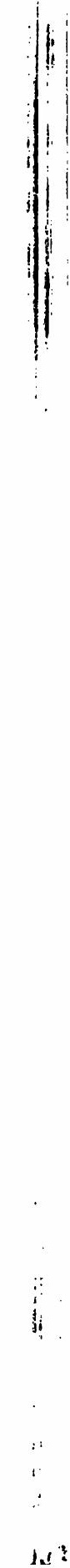

